\title{
URINARY LIVER TYPE-FATTY ACID BINDING PROTEIN AND PLASMA CYSTATIN C AS EARLY PREDICTORS OF CONTRAST INDUCED ACUTE KIDNEY INJURY
}

\author{
Essam M. Lotfy, Mabrouk I. Ismail, Aly M. Shindy, Lamiaa A. Mohamed* \\ Internal medicine department and clinical pathology department
}

\begin{abstract}
Background: Contrast-induced acute kidney injury (CI-AKI) continues to have an increasing incidence, representing the third most common cause of hospital acquired acute kidney injury. It is a syndrome in which an acute renal dysfunction is diagnosed after the intravascular injection of contrast media. Acute renal injury is typically diagnosed by measuring serum creatinine that is an unreliable indicator during acute changes in kidney function; thus, the need for early sensitive biomarkers to detect acute kidney injury before the rise of creatinine has emerged. Urinary Liver type fatty acid binding protein is a newly emerging biomarker that might represent an early, sensitive and non-invasive biomarker for acute renal injury. Cystatin $\mathrm{C}$ is a cysteine protease inhibitor that demonstrated a high diagnostic value to detect $\mathrm{AKI}$ on the two days before creatinine elevation. Objective: The aim of our study was to elucidate if urinary L-FABP and plasma Cystatin C can be early predictors of AKI after contrast adminstration. Subject and methods: thirty three patients were included in this study, they were divided into two main groups; Group (I): 16 patients underwent coronary angiography for dioagnostic and therapeutic purposes, Group (II): 17 patients underwent computerized tomography using IV (high-osmolar) contrast media; then classified after the procedure to AKI group and Non AKI group according to the change in serum creatinine after 24 hours. Results: the basal value of both plasma cystatin c and urinary L-FABP is significantly higher in AKI vs non AKI groups indicating predictive value of both biomarkers before contrast exposure (AUC of urinary L-FABP $=0.837(95 \% \mathrm{CI}$; $0.673-1.001)$; AUC of plasma Cystatin C $=0.742(95 \% \mathrm{CI} ; 0.600-0.925))$. After contrast exposure, both both plasma cystatin c and urinary L-FABP showed a highly statistically significiant elevation at 6 hours in the AKI group compared to the non AKI group, while there was no statistically significiant difference in serum creatinine $(\mathrm{mg} / \mathrm{dl})$ that showed significant elevation only after 24 hours; thus, both plasma cystatin c and urinary L-FABP may serve as early predictors of AKI after contrast adminstration before any significant change in serum creatinine (AUC of urinary L-FABP $=1(95 \% \mathrm{CI} ; 1$ - 1); AUC of plasma Cystatin C =1 (95\%CI; $1-1)$ ). Conclusion: urinary L-FABP and plasma Cystatin C can be considered as predictive biomarkers of contrast induced nephropathy before contrast exposure and as early biomarkers after contrast exposure instead of serum creatinine, as their levels start to rise about 24 hours before any significant change in serum creatinine. Further studies are recommended using large number of patient.
\end{abstract}

Keywords: L-FABP, cystatin c, contrast-induced nephropathy, high osmolar contrast.

\section{INTRODUCTION}

A $\mathrm{KI}$ is defined by an abrupt decrease in kidney function that includes, but is not limited to, ARF. It is a broad clinical syndrome encompassing various etiologies, including specific kidney diseases (e.g., acute interstitial nephritis, acute glomerular and vasculitic renal diseases); nonspecific conditions (e.g, ischemia, toxic injury); as well as extrarenal pathology (e.g., prerenal azotemia, and acute postrenal obstructive nephropathy) [1].

The incidence of hospital acquired renal failure is on the rise and CIN is the third most common cause of hospital-acquired renal failure after hypoperfusion-induced and drug-induced renal failure. CIN contributes to approximately $11 \%$ of hospital acquired renal failure [2].

Contrast-induced acute kidney injury (CI-AKI), previously known as contrast-induced nephropathy (CIN), is a syndrome in which an acute renal dysfunction is diagnosed after the intravascular injection of contrast media [3].
The new KDIGO definition of AKI applies to CI-AKI and helps unify the clinical and research language around this common problem. This definition states that $\mathrm{AKI}$ is defined as any of the following: an increase in SCr of $\geq 0.3 \mathrm{mg} / \mathrm{dl}(\geq 26.5$ $\mu \mathrm{mol} / \mathrm{l}$ ) within $48 \mathrm{~h}$, an increase in $\mathrm{SCr}$ to $\geq 1.5$ times the baseline that is known or presumed to have occurred within the prior 7 days, or urine volume < $0.5 \mathrm{ml} / \mathrm{kg} / \mathrm{h}$ for $6 \mathrm{~h} \mathrm{[1]}$.

Serum creatinine, the currently accepted 'gold standard' to diagnose AKI, is a delayed and inadequate marker of acute changes in renal function. In AKI, serum creatinine elevation that reflects the development and severity of kidney damage does not occur until days after renal tubular injury has begun [4]; thus, there is a need for new specific biomarkers that identify kidney injury early and that can replace serum creatinine in both the definition of AKI for epidemiological and study purposes as well as in guiding individual patient management [5]

Fatty acid binding proteins are small $(15 \mathrm{kDa})$ cytoplasmatic proteins abundantly expressed in 
tissues with active fatty acid metabolism [6]. The liver type fatty acid binding protein is a newly emerging biomarker that has antioxidant properties, and enhanced expression in proximal tubule cells and subsequent urinary excretion are known to reflect the presence of tubular injury [7]. Urine LFABP shows promise as an early, accurate biomarker of AKI [8].

Cystatin $\mathrm{C}(\mathrm{CysC})$ is a $13-\mathrm{kD}$ cysteine protease inhibitor that is synthesized in all nucleated cells at a steady state. It is freely filtered by the glomerulus, not secreted by renal tubules, and completely metabolized at the level of the renal tubules [9].

Unlike creatinine, non-renal variables (e.g. age, gender, and muscle mass) do not seem to have much effect on cystatin $\mathrm{C}$ levels and many investigations have demonstrated that serum levels reflect GFR better than serum creatinine biomarker [10]. Serum and urine cystatin $\mathrm{C}$ measurements are superior to conventional biomarkers, such as urine output, urine protein, urine albumin, and serum blood-urea nitrogen and creatinine. [11]. In the intensive care setting, a 50\% increase in serum cystatin C predicted acute kidney injury 1 to 2 days before the rise in serum creatinine [12].

This work was carried out to elucidate whether urinary L-FABP and plasma Cystatin C can be early predictors of AKI after contrast adminstration

\section{SUBJECTS AND METHODS}

This work has been carried out in collaboration between the Internal Medicine, cardiology, radiology and Clinical pathology Departments, Faculty of Medicine, Zagazig University, during the period from September 2011 to October 2012.

* Subjects:

A total number of 33 patients were included and classified into two main groups:

1) Group I: which included 16 patients (10 males and 6 females) with age ranged from 32 years to 55 years with a mean values \pm SD of $42.44 \pm$ 6.45years. Their basal serum creatinine level ranged from $0.7 \mathrm{mg} / \mathrm{dl}$ to $1.1 \mathrm{mg} / \mathrm{dl}$ with a mean values + SD of $0.91 \pm 0.16 \mathrm{mg} / \mathrm{dl}$.

These patients underwent coronary angiography for diagnostic and therapeutic purposes using the IV (high-osmolar) contrast agent ioxithalamate (Telebrix)

2) Group II: which included 17 patients (9 males and 8 females) with age ranged from 26 years to 50 years with a mean values \pm SD of $39.05 \pm 6.7$ years. Their basal serum creatinine level ranged from $0.7 \mathrm{mg} / \mathrm{dl}$ to $1.1 \mathrm{mg} / \mathrm{dl}$ with a mean values \pm $\mathrm{SD}$ of $0.87 \pm 0.17 \mathrm{mg} / \mathrm{dl}$
These patients underwent computerized tomography (CT) for various purposes including CT chest (5 patients), CT brain (7 patients), Abdominal and pelvic CT (5 patients), using the same IV (high-osmolar) contrast medium as coronary angiography (ioxithalamate (Telebrix)), with the mean value of contrast volume \pm SD of $73.5 \pm 19.9$ $\mathrm{ml}$.

The patients were classified after the proceduer into 2 groups :

AKI group: The creatinine level was elevated either by $25 \%$ of the basal level or by $0.3 \mathrm{mg} / \mathrm{dl}$ above the basal level after 24 hours. It included 11 patients ( 7 males and 4 females) with age ranged from 35 years to 55 years with a mean values \pm SD of $42 \pm 5.9$ years. Their BMI ranged from 23 to 27 with a mean value + SD of $25.3 \pm 2.1$.

No AKI group: No rise of the serum creatinine level more than $25 \%$ of the basal level or more than $0.3 \mathrm{mg} / \mathrm{dl}$ above the basal level after $24 \mathrm{~h}$. It included 22 patients ( 15 male and 7 female) with age ranged from 26 years to 50 years with mean values \pm SD of $40.04 \pm 7.1$ years. Their BMI ranged from 24 to 27 with mean value \pm SD of $25.5 \pm 1.4$.

\section{Exclusion critieria :}

All subjects were selected to be free from hepatic diseases, renal diseases (serum creatinine > $1.4 \mathrm{mg} / \mathrm{dl}$ ), diabetes melliteus, hypertension, autoimmune diseases, sepsis, inflammatory conditions, and malignancy.

All paticipants of this study were subjected to a written consent.

* Methods:

All subjects of the study were subjected to the following:-

A) Full history and thorough clinical examination: According to the included work sheet with special stress on history of renal diseases. Body mass index was calculated according to the following formula:

$$
\mathrm{BMI}=\frac{\operatorname{mass}(\mathrm{kg})}{(\operatorname{height}(\mathrm{m}))^{2}}
$$

\section{B) Routine investigations:}

They were all done according to the methods applied in the clinical pathology laboratories of zagazig university hospitals and include:

1- Urine analysis (for glucose, acetone, protein, $\mathrm{pH}$, bilirubin and leukocytes by urine strips).

2- Complete blood picture (by automated blood counter).

3- Fasting plasma glucose level by colorimetric method 
4- Liver function tests: serum bilirubin (total and direct), serum albumin, serum alanine transferase and aspartate transferase measured by kinetic method [13].

5- Renal function tests: serum creatinine [14], serum urea by colorimetric method [15].

6- Calcuation of glomerular filtration rate using MDRD equation

GFR $(\mathrm{mL} / \mathrm{min} / 1.73 \mathrm{~m} 2)=175 \times(\mathrm{Scr})^{-1.154} \times($ Age $)$

${ }^{0.203} \mathrm{x}$ (0.742 if female) [16].

7- Lipid profile: included:

a) Serum total cholesterol level by enzymatic colorimetric determination of total cholesterol [17].

b) Serum triglycerides by enzymatic method developed by [18].

c) HDL- cholesterol by method developed by [19].

d) LDL- cholesterol [20].

8- Transthoracic echocardiography

C) Specific investigations: include

1-Meaurment of L-FABP by ELISA:

Human liver type-fatty acid-binding protein (LFABP) ELISA kit allows for the in vitro quantitative determination of human L-FABP concentrations in serum, Plasma, Urine, and other biological fluids. Urinary levels of L-FABP in spot urine samples were measured by ELISA before contrast administration, 6 hours and 24 hours after contrast administration.

2- Meaurment of Cystatin C by ELISA:

BIOVENDOR Cystatin $\mathrm{C}$ is an Enzyme Immunoassay (ELISA) for the quantitative determination of Cystatin $\mathrm{C}$ levels in human plasma or serum [21].

Collection of blood samples:

$6 \mathrm{ml}$ of peripheral venous blood were taken from each subject under complete aseptic conditions into EDTA-treated tubes, and then centrifuged at $3000 \mathrm{rpm}$ for 5 minutes. Samples were separated and stored at $-80^{\circ} \mathrm{C}$, for measurement of basal values of plasma Cystatin C. This process was repeated after 6 and 24_hours of the procedure.

\section{Statistical analysis:-}

Data were analyzed with SPSS version 15.0 (statistical package for the Social Science, Chicago, IL). Quantitative data were expressed as mean \pm standard deviation (SD) or standard error (SE). $\mathrm{SE}=\mathrm{SD} / \mathrm{square}$ root of patients number which was used in case of big SD, data were analyzed by independent sample, paired t test and one way analysis of variance (ANOVA). While qualitative data were expressed as number and percentage and were analyzed by Chi square $\left(\chi^{2}\right)$ test. Correlation was done using Pearson correlation test. The receiver operating characteristic (ROC) curve and 95\% confidence interval (CI) was performed to determine cutoff values for the studied biomarkers. Sensitivity, specificity, positive predictive value (PPV) and negative predictive value (NPV) were determined. P-value was considered significant if $<0.05$ and highly significant if $<0.001$.

\section{RESULTS}

The clinical and laboratory data of studied groups (I \& II) are shown in table (1); statistically significant difference was found between studied groups (I \& II) as regard amount of IV (high osmolar) contrast $(\mathrm{P}<0.05)$, but no statistically significant differences were found between studied groups (I \& II) as regard age, sex, BMI, and $\mathrm{Hb}$; also no statistically significant difference was found in the mean values \pm SD between studied groups (I \& II) as regard basal serum creatinine $(\mathrm{mg} / \mathrm{dl})$, basal urinary L-FABP (ng/dl), basal plasma Cystatin $\mathrm{C}(\mathrm{mg} / \mathrm{l})$, and number of AKI cases $(\mathrm{P}>0.05)$.

The clinical and laboratory data of resultant groups after adminstration of IV (high-osmolar) contrast (group A (AKI) \& group B (Non AKI)) are shown in table (2); no statistically significant differences were found between the two groups (AKI \& Non AKI) as regard Age, BMI, Hb, and basal serum creatinine $(\mathrm{mg} / \mathrm{dl})$. Whereas, there was statistically significant difference as regard the amount of IV (high-osmolar) contrast $(\mathrm{ml})$, basal urinary L-FABP (ng/dl), and basal plasma Cystatin $\mathrm{C}(\mathrm{mg} / \mathrm{l})$.

The time course of the stuided biomarkers among patients with AKI versus without AKI is shown in table (3) and illustrated in figures (1, 2, 3); there was a highly statistically significant difference along the time course for urinary LFABP (ng/dl), plasma Cystatin C (mg/l) and serum creatinine $(\mathrm{mg} / \mathrm{dl})$ in patient with AKI.

Whereas in patients without AKI, there was a highly statistical significant difference along the time course for urinary L-FABP (ng/dl), while no statistical significant difference along the time course for plasma Cystatin $\mathrm{C}(\mathrm{mg} / \mathrm{l})$ and serum creatinine $(\mathrm{mg} / \mathrm{dl})$ was present.

When we assessed the validity of the basal values of the studied biomarkers as predictors of AKI; setting a cutoff value of $10.5(\mathrm{ng} / \mathrm{dl})$ for urinary L-FABP yielded a sensitivity and specificity of $81.8 \%$ and $77.3 \%$ respectively with positive predictive value (PPV) of $64.3 \%$ and negative predictive value (NPV) of $89.5 \%$; whereas, setting a cutoff value of $0.875(\mathrm{mg} / \mathrm{l})$ for plasma cystatin C 
yielded a sensitivity and specificity of $81.8 \%$ and $59.1 \%$ respectively with PPV of $50 \%$ and NPV of $86.7 \%$ (Table 4).

Table (5) shows the validity of the studied biomarkers as predictors of AKI 6 hours after contrast administration. Setting a cutoff value of $17.5(\mathrm{ng} / \mathrm{dl})$ for urinary L-FABP yielded a sensitivity and specificity of $100 \%$ and $90.9 \%$ respectively with PPV of $84.6 \%$ and NPV of $100 \%$. Setting a cutoff value of $1.025(\mathrm{mg} / \mathrm{l})$ for plasma cystatin $\mathrm{C}$ yielded a sensitivity and specificity of $100 \%$ and $95.5 \%$ respectively with PPV of $91.7 \%$ and NPV of $100 \%$.
Figure (4) shows the receiver operating characteristic (ROC) curve of the studied biomarkers before contrast exposure, the Area under the curve (AUC) of urinary L-FABP $=0.837(95 \%$ CI; $0.673-1.001$ ); AUC of plasma Cystatin $\mathrm{C}=$ $0.742(95 \% \mathrm{CI} ; 0.600-0.925)$; AUC of serum creatinine $=0.636(95 \% \mathrm{CI} ; 0.470-0.856)$.

Figure (5) shows the ROC curve of the studied biomarkers 6 hours after contrast exposure, AUC of urinary L-FABP $=1(95 \% \mathrm{CI} ; 1-1)$; AUC of plasma Cystatin $\mathrm{C}=1(95 \% \mathrm{CI} ; 1-1)$; AUC of serum creatinine $=0.683(95 \% \mathrm{CI} ; 0.443-0.830)$.

Table (1): Demographic and Laboratory data of the studied groups.

\begin{tabular}{|c|c|c|c|c|}
\hline & $\begin{array}{c}\text { CRONARY } \\
\text { ANGIOGRAPHY } \\
\text { (Group I) } \\
(n=16) \\
(\text { Mean } \pm \text { SD) }\end{array}$ & $\begin{array}{c}\text { CT WITH CONTRAST } \\
\begin{array}{c}(\text { Group II }) \\
(\mathrm{n}=17) \\
(\text { Mean } \pm \text { SD })\end{array}\end{array}$ & $\begin{array}{c}\text { Test of } \\
\text { significance }\end{array}$ & $\mathbf{P}$ \\
\hline Age (Years) & $42.44 \pm 6.45$ & $39.05 \pm 6.7$ & $\mathrm{t}=1.47$ & $0.15 \mathrm{NS}$ \\
\hline \multirow{3}{*}{$\begin{array}{c}\text { Male } \\
\text { Female } \\
\text { Hb (g/dl) }\end{array}$} & $10(62.5 \%)$ & $9(52.9 \%)$ & & \\
\hline & $6(37.5 \%)$ & $8(47.1 \%)$ & $\chi^{2}=0.31$ & $0.57 \mathrm{NS}$ \\
\hline & $13.04 \pm 0.5$ & $13.02 \pm 0.4$ & $\mathrm{t}=0.12$ & $0.91 \mathrm{NS}$ \\
\hline BMI $\left(\mathrm{Kg} / \mathrm{m}^{2}\right)$ & $25.3 \pm 1.9$ & $25.5 \pm 1.5$ & $\mathrm{t}=0.49$ & $0.69 \mathrm{NS}$ \\
\hline Contrast volume (ml) & $108.12 \pm 40.4$ & $73.5 \pm 19.9$ & $t=3.15$ & $0.004 \mathrm{~S}$ \\
\hline $\begin{array}{c}\text { Basal serum Creatinine } \\
(\mathrm{mg} / \mathrm{dl})\end{array}$ & $0.91 \pm 0.16$ & $0.87 \pm 0.17$ & $\mathrm{t}=0.3$ & $0.76 \mathrm{NS}$ \\
\hline $\begin{array}{c}\text { Basal urinary L-FABP } \\
(\mathbf{n g} / \mathrm{ml})\end{array}$ & $10.12 \pm 3.34$ & $9.35 \pm 3.12$ & $t=0.68$ & $0.49 \mathrm{NS}$ \\
\hline $\begin{array}{c}\text { Basal plasma cystatin C } \\
(\mathrm{mg} / \mathrm{l})\end{array}$ & $0.875 \pm 0.078$ & $0.888 \pm 0.082$ & $\mathrm{t}=0.45$ & $0.65 \mathrm{NS}$ \\
\hline $\begin{array}{c}\text { Incidence of AKI (number of } \\
\text { patients) }\end{array}$ & $\begin{array}{l}37.5 \% \\
(\mathrm{n}=6)\end{array}$ & $\begin{array}{l}29.4 \% \\
(\mathrm{n}=5)\end{array}$ & $\mathbf{X}^{2}=0.24$ & $0.62 \mathrm{NS}$ \\
\hline
\end{tabular}

Table (2): Demographic and Laboratory data of the resultant groups after adminstration of IV (highosmolar) contrast.

\begin{tabular}{|c|c|c|c|c|}
\hline & $\begin{array}{c}\text { Group A (AKI } \\
\text { group) } \\
(\mathbf{n}=11) \\
(\text { Mean } \pm \text { SD) } \\
\end{array}$ & $\begin{array}{c}\text { Group B (Non AKI } \\
\text { group) } \\
(\mathrm{n}=22) \\
(\text { Mean } \pm \text { SD }) \\
\end{array}$ & t-test & $\mathbf{P}$ \\
\hline Age (Years) & $42 \pm 5.9$ & $40.04 \pm 7.1$ & 0.78 & $0.43 \mathrm{NS}$ \\
\hline BMI $\left(\mathrm{Kg} / \mathrm{m}^{2}\right)$ & $25.3 \pm 2.1$ & $25.5 \pm 1.4$ & 0.47 & $0.76 \mathrm{NS}$ \\
\hline $\mathrm{Hb}(\mathrm{g} / \mathrm{dl})$ & $12.96 \pm 0.52$ & $13.06 \pm 0.47$ & 0.57 & $0.56 \mathrm{NS}$ \\
\hline $\begin{array}{c}\text { Amount of IV } \\
\text { (high-osmolar) contrast (ml) }\end{array}$ & $114.09 \pm 47.89$ & $78.4 \pm 19.96$ & 3.04 & $0.005 \mathrm{~S}$ \\
\hline Basal serum Creatinine (mg/dl) & $0.92 \pm 0.15$ & $0.86 \pm 0.16$ & 1.65 & $0.11 \mathrm{NS}$ \\
\hline Basal urinary L-FABP (ng/ml) & $12.18 \pm 3.06$ & $8.5 \pm 2.5$ & 3.66 & $0.001 \mathrm{~S}$ \\
\hline Basal plasma Cystatin C (mg/l) & $0.94 \pm 0.06$ & $0.84 \pm 0.12$ & 2.6 & $0.013 \mathrm{~S}$ \\
\hline
\end{tabular}




\begin{tabular}{|c|c|c|c|c|c|c|}
\hline $\begin{array}{l}\text { Patients } \\
\text { category }\end{array}$ & Biomarker & Basal & 6hs & 24hs & $\mathbf{F}$ & $\mathbf{P}$ \\
\hline \multirow{3}{*}{$\begin{array}{c}\text { Patients with } \\
\text { AKI }\end{array}$} & $\begin{array}{c}\text { Urinary L-FABP } \\
(\mathrm{ng} / \mathrm{ml})\end{array}$ & $12.18 \pm 3.06$ & $29.27 \pm 5.49$ & $63.72 \pm 9.35$ & 244.563 & $\begin{array}{c}0.000 \\
\text { HS }\end{array}$ \\
\hline & $\begin{array}{c}\text { Plasma Cystatin C } \\
(\mathrm{mg} / \mathrm{l})\end{array}$ & $0.929 \pm 0.059$ & $1.352 \pm 0.065$ & $1.611 \pm 0.053$ & 456.716 & $\begin{array}{c}0.000 \\
\text { HS }\end{array}$ \\
\hline & $\begin{array}{c}\text { Serum Creatinine } \\
(\mathrm{mg} / \mathrm{dl})\end{array}$ & $0.92 \pm 0.15$ & $0.93 \pm 0.15$ & $1.46 \pm 0.15$ & 162.303 & $\begin{array}{c}0.000 \\
\text { HS }\end{array}$ \\
\hline \multirow{3}{*}{$\begin{array}{c}\text { Patients } \\
\text { without AKI }\end{array}$} & $\begin{array}{c}\text { Urinary L-FABP } \\
(\mathrm{ng} / \mathrm{ml})\end{array}$ & $8.5 \pm 2.5$ & $11.9 \pm 3.85$ & $14.59 \pm 4.86$ & 45.010 & $\begin{array}{c}0.000 \\
\text { HS }\end{array}$ \\
\hline & $\begin{array}{c}\text { Plasma Cystatin C } \\
(\mathrm{mg} / \mathrm{l})\end{array}$ & $0.858 \pm 0.078$ & $0.867 \pm 0.089$ & $0.873 \pm 0.11$ & 1.69 & $\begin{array}{l}0.19 \\
\text { NS }\end{array}$ \\
\hline & $\begin{array}{l}\text { Serum Creatinine } \\
(\mathrm{mg} / \mathrm{dl})\end{array}$ & $0.86 \pm 0.16$ & $0.87 \pm 0.11$ & $0.87 \pm 0.15$ & 2.36 & $\begin{array}{l}0.11 \\
\mathrm{NS}\end{array}$ \\
\hline
\end{tabular}

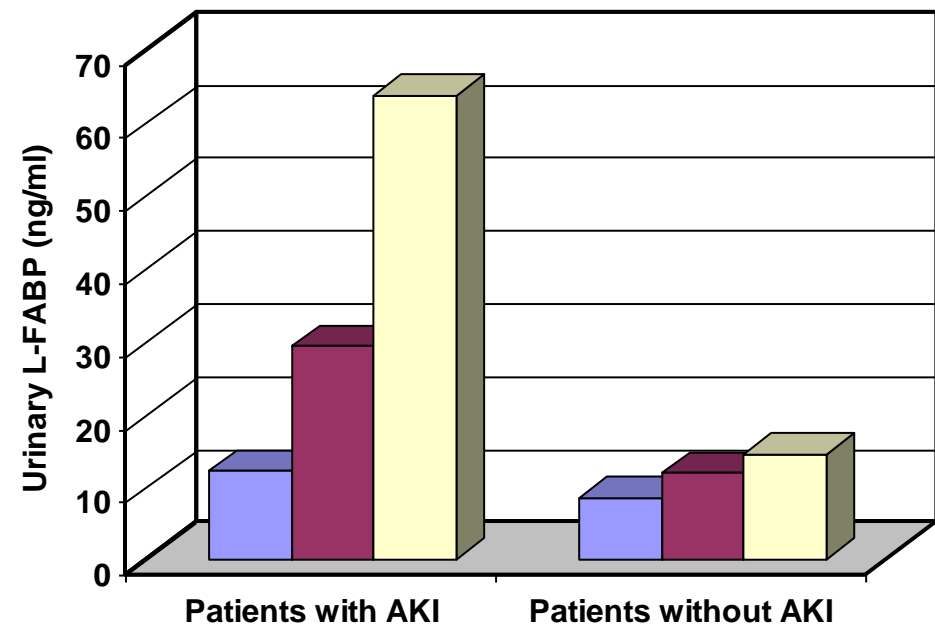

Figure (1): Time-course of urinary L-FABP (ng/ml) between patients with AKI versus those without AKI.

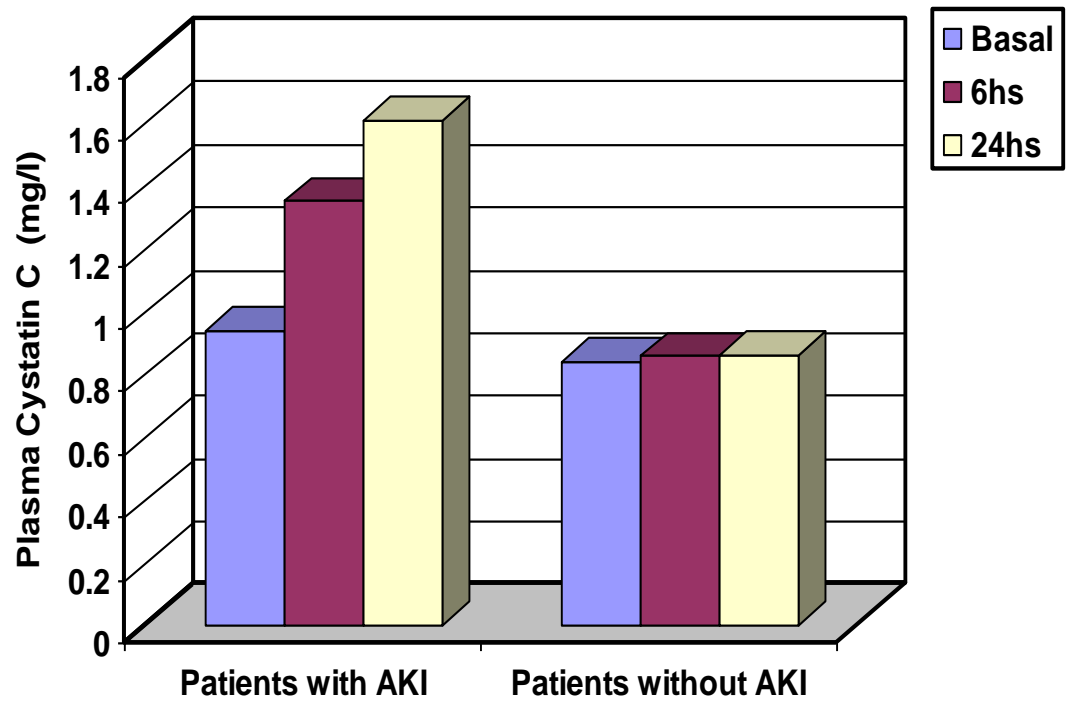


Figure (2): Time-course of plasma Cystatin C (mg/l) between patients with AKI versus those without AKI.

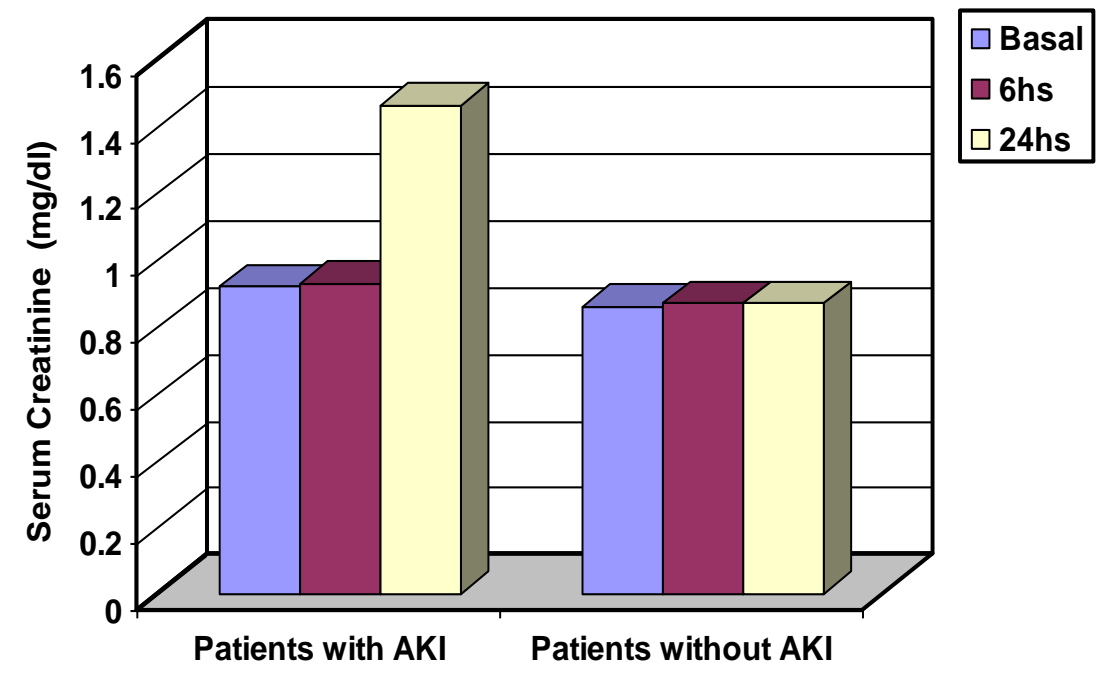

Figure (3): Time-course of serum creatinine (mg/dl) between patients with AKI versus those without AKI.

Table (4): Validity of of basal values of the studied biomarkers as predictors of AKI before contrast administration.

\begin{tabular}{cccccc}
\hline Biomarker & Cutoff values & Sensitivity & Specificity & PPV & NPV \\
\hline $\begin{array}{c}\text { Urinary L-FABP } \\
(\mathbf{n g} / \mathbf{m l})\end{array}$ & $10.5 \mathrm{ng} / \mathrm{dl}$ & $81.8 \%$ & $77.3 \%$ & $64.3 \%$ & $89.5 \%$ \\
\hline Plasma Cystatin C (mg/l) & $0.875 \mathrm{mg} / \mathrm{l}$ & $81.8 \%$ & $59.1 \%$ & $50.0 \%$ & $86.7 \%$ \\
\hline
\end{tabular}

Table (5): Validity of of the studied markers as predictors for AKI 6 hours after contrast administration

\begin{tabular}{cccccc}
\hline Biomarker & Cuttoff value & Sensitivity & Specificity & PPV & NPV \\
\hline $\begin{array}{c}\text { Urinary L-FABP } \\
(\mathbf{n g} / \mathbf{m l})\end{array}$ & $17.5 \mathrm{ng} / \mathrm{dl}$ & $100 \%$ & $90.9 \%$ & $84.6 \%$ & $100 \%$ \\
\hline Plasma Cystatin C (mg/l) & $1.025 \mathrm{mg} / 1$ & $100 \%$ & $95.5 \%$ & $91.7 \%$ & $100 \%$ \\
\hline
\end{tabular}




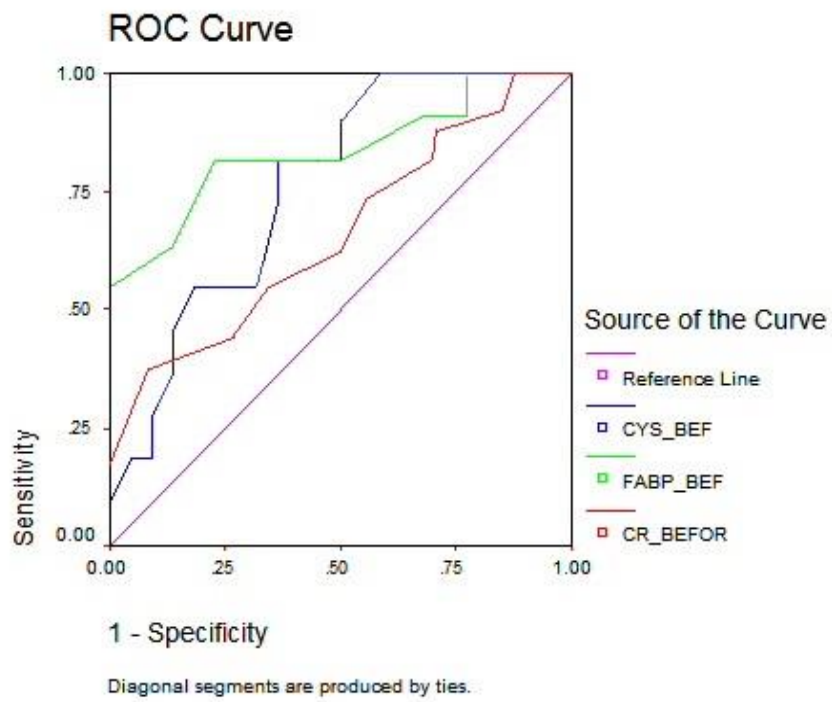

Figure (4): ROC curve of cystatin C, LFABP, and creatinine before contrast exposure.

\section{DISCUSSION}

Contrast media (CM) are increasingly used in diagnostic and interventional procedures. This results in raising the incidence of contrast induced nephropathy (CIN) [22]. Among all procedures utilizing CM for diagnostic or therapeutic purposes, coronary angiography and percutaneous coronary interventions (PCI) are associated with the highest rates of CIN [3].

AKI is recently defined by the KDIGO guidelines as any of the following: Increase in $\mathrm{SCr}$ by $\geq 0.3 \mathrm{mg} / \mathrm{dl}(\geq 26.5 \mu \mathrm{mol} / \mathrm{l})$ within 48 hours; increase in $\mathrm{SCr}$ to $\geq 1.5$ times baseline, which is known or presumed to have occurred within the prior 7 days; or urine volume $<0.5 \mathrm{ml} / \mathrm{kg} / \mathrm{h}$ for 6 hours. This new KDIGO definition of AKI applies also to CI-AKI [1].

The incidence of hospital acquired renal failure is on the rise and CIN is the third most common cause of hospital-acquired renal failure. CIN contributes to approximately $11 \%$ of hospital acquired renal failure [3].

Acute renal injury is typically diagnosed by measuring serum creatinine. Unfortunately, creatinine is an unreliable indicator during acute changes in kidney function [23].

There is a need for new specific biomarkers that identify kidney injury early and that can replace serum creatinine in both the definition of AKI for

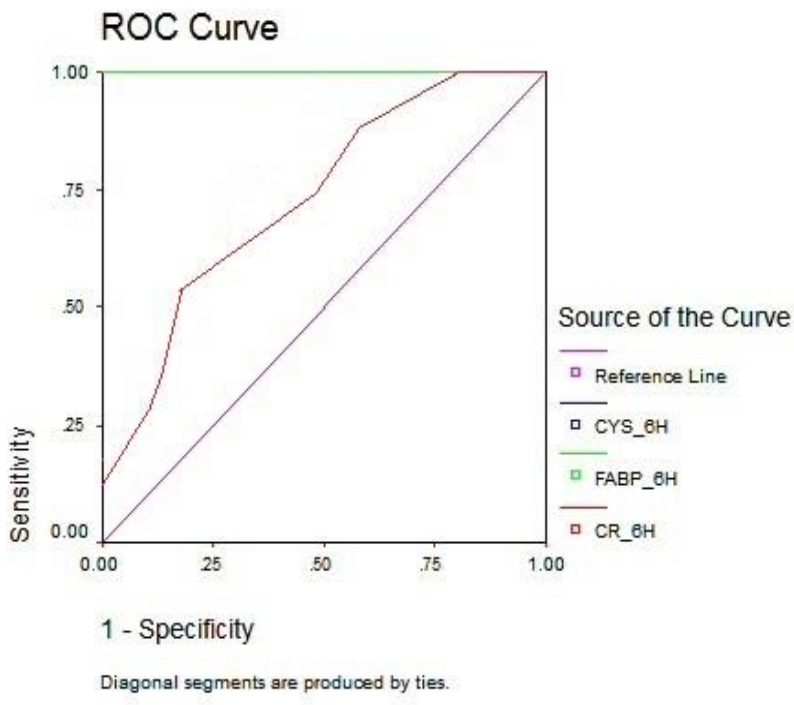

Figure (5): ROC curve of cystatin C, LFABP, and creatinine 6 hours after contrast exposure.

epidemiological and study purposes as well as in guiding individual patient management [5].

Fatty acid binding proteins are small $(15 \mathrm{kDa})$ cytoplasmatic proteins abundantly expressed in tissues with active fatty acid metabolism. Their primary function is the facilitation of long-chain fatty acid transport, the regulation of gene expression and the reduction of oxidative stress [6]. L-FABP is a newly emerging biomarker that has antioxidant properties, and enhanced expression in proximal tubule cells and subsequent urinary excretion are known to reflect the presence of tubular injury [7].

Cystatin $\mathrm{C}(\mathrm{Cys} C)$ is a $13-\mathrm{kD}$ cysteine protease inhibitor that is synthesized in all nucleated cells at a steady state. It is freely filtered by the glomerulus, not secreted by renal tubules, and completely metabolized at the level of the renal tubules. As blood levels of cystatin $\mathrm{C}$ are not significantly affected by age, gender, race, or muscle mass, these properties have made it an attractive marker of the GFR in chronic kidney disease [9].

In the intensive care setting, a 50\% increase in serum cystatin $C$ predicted acute kidney injury 1 to 2 days before the rise in serum creatinine [24].

The aim of our work is to evaluate the hypothesis that urinary L-FABP and plasma Cystatin $\mathrm{C}$ could represent sensitive early biomarkers of renal injury in patients with normal 
serum creatinine receiving iodinated intravenous contrast.

Our study was conducted on a total number of 33 patients divided into 2 groups. Group I included 16 patients underwent percutaneous cronary anigography and group II included 17 patients underwent computerized tomography with the IV (high-osmolar) contrast media ioxithalamate (Telebrex).

There were no statisitically significant differences between the 2 groups in the demographic or laboratory parameters; while there was a statsitically significant difference between the 2 groups in the amount of IV (high-osmolar) contrast media due to the nature of both proceduers; this resulted in higher incidence of AKI in the coronary anigiography group $(37.5 \%)$ than in the computerized tomography group $(29.4 \%)$ with a relative risk (RL) of 1.28.

After the proceduer the patients were classified into 2 other groups according to occurrence of AKI:

Group A (AKI group): includes 11 patients who experienced an elevation of serum creatinine either by $25 \%$ of the basal level or by $0.3 \mathrm{mg} / \mathrm{dl}$ above the basal level after 24 hours of adminstration of contrast media.

Group B (Non AKI group): includes 22 patients who didn't experience an elevation of serum creatinine either by $25 \%$ of the basal level or by 0.3 $\mathrm{mg} / \mathrm{dl}$ above the basal level after 24 hours adminstration of contrast media.

About $33 \%$ of the present studied patients (11 patients) fulfilled the criteria of contrast nephropathy with more cases in the percuteanous coronary angiography group (6 patients, 54.5\%) than in the computerized tomography group (5 patients, $45.5 \%$ ).

When comparing baseline criteria of the two groups after administration of IV contrast, the amount of contrast administered, basal plasma cystatin $\mathrm{C}$ and basal urinary L-FABP were significantly higher in AKI group than in non-AKI group, this implies that each of these parameters has a predictive value for the occurrence of contrast nephropathy. Whereas, there were no statistically significant difference between the two groups regarding age (years), BMI $\left(\mathrm{Kg} / \mathrm{m}^{2}\right), \mathrm{Hb}(\mathrm{g} / \mathrm{dl})$, and Basal serum Creatinine (mg/dl).

These results come in agreement with Nakamura et al., (2006) [25]; who found that before angiography, urinary L-FABP levels were significantly greater in the contrast medium-induced nephropathy group $(18.5+/-12.8$ microg/g $\mathrm{Cr})$, than in the non-contrast medium-induced nephropathy group $(7.4+/-4.4$ microg/g $\mathrm{Cr}$; $\mathrm{P}<0.01)$ or healthy volunteers $(5.4+/-4.4$ microg/g $\mathrm{Cr}$; $\mathrm{P}<0.01)$; whereas serum creatinine level and creatinine clearance differed little between two groups.

Our study showed statistically highly significant differences between each of the $6 \mathrm{~h}$ and $24 \mathrm{~h}$ urinary L-FABP (ng/dl) versus basal urinary L-FABP (ng/dl), in the AKI group. Similarly, there were statistically highly significant differences between the $6 \mathrm{~h}$ and $24 \mathrm{~h}$ plasma Cystatin $\mathrm{C}(\mathrm{mg} / \mathrm{l})$ in comparison to basal plasma Cystatin C $(\mathrm{mg} / \mathrm{l})$. Serum creatinine at $6 \mathrm{~h}$ failed to show statistically significant difference with the basal value, while there was highly significant difference at $24 \mathrm{~h}$ after administration of IV (high-osmolar) contrast.

Statistically highly significant differences in urinary L-FABP (ng/dl) was also present in the Non AKI group at $6 \mathrm{~h}$ and $24 \mathrm{~h}$ after administration of IV (high-osmolar) contrast compared to their basal levels; whereas both serum creatinine and plasma Cystatin C (mg/l) didn't show any significant change at $6 \mathrm{~h}$ or at $24 \mathrm{~h}$ after contrast administration compared to baseline value.

This can be explained by the fact that urinary LFABP expression in the proximal tubules may be upregulated under tubular stress (e.g., tubular ischemia, toxic insult), and urinary excretion of LFABP from the proximal tubules may increase before the occurrence of cellular structural damage [26].

These results are similar to those of Kato et al., (2008) [27]; who found that urinary L-FABP levels were significantly increased after coronary angiography, suggesting transient proximal tubular damage by contrast medium, although the classical markers were not useful for predicting or detecting CIN. Another study carried out by BachorzewskaGajewska et al., (2009) [28]; supported this finding, where the 25 included patients underwent PCI; none of them fulfilled the criteria of contrast nephropathy, despite there was highly significant elevation of urinary L-FABP as early as 4 hours after contrast administration $(25.90 \pm 21.93 \mathrm{pg} / \mathrm{ml})$ and at 24 hours $(33.49 \pm 26.41 \mathrm{pg} / \mathrm{ml})$ compared to a baseline value of $3.76 \pm 1.52 \mathrm{pg} / \mathrm{ml}$.

Similar result was obtained by Ohta et al., (2005) [29]; who found that in patients without renal dysfunction and who had undergone angiography using iodinated contrast media, On the day following angiography, the urinary excretion of L-FABP was markedly increased by $578 \%$ $(\mathrm{p}<0.001)$; and then swiftly returned to the basal 
level on the second day after the angiography. No patient showed an increase in serum creatinine concentration. These results suggest that the urinary excretion of L-FABP sensitively reflects the injurious stress on renal tubules.

Contrary to these findings, In the study by Nakamura et al., (2006) [25]; One and 2 days after angiography, urinary L-FABP levels in the contrast medium-induced nephropathy group increased significantly to $46.8 \pm 30.5 \mu \mathrm{g} / \mathrm{g}$ Cr and $38.5 \pm 28.5$ $\mu \mathrm{g} / \mathrm{g} \mathrm{Cr}$, respectively; while urinary L-FABP levels in the non-contrast medium-induced nephropathy group showed little change throughout the experimental period.

There were highly significant statistical differences between both urinary L-FABP (ng/dl) and plasma cystatin $\mathrm{C}(\mathrm{mg} / \mathrm{l})$ in the AKI group and their values in the Non AKI group at $6 \mathrm{~h}$ and $24 \mathrm{~h}$ after contrast administration. As regard serum creatinine $(\mathrm{mg} / \mathrm{dl})$ values, there was no statistically significant difference between the AKI and the Non AKI groups at $6 \mathrm{~h}$; while, there was highly significant statistical difference at $24 \mathrm{~h}$ after contrast administration.

Manabe et al., (2012) [30]; confirmed that serum Creatinine and urinary L-FABP levels in the CI-AKI group were significantly higher than those in the non-CI-AKI group, on days 1 and 2 after contrast medium administration.

Shaker et al., (2010) [31]; found that Serum cystatin C and NGAL could be valuable in the detection of early renal impairment after coronary angiography, serum cystatin $\mathrm{C}$ concentration was increased significantly only 24 hours after coronary angiography but not at 4 hours.

Conflicting results, regarding the time course of L-FABP, were obtained by Malyszko et al., (2009) [32]; who performed a study on 140 patients (i.e., 70 type 2 diabetic patients in comparison to 70 nondiabetic patients) with normal serum creatinine undergoing cardiac catheterization; they evaluated Serum, urinary NGAL, cystatin C, urinary KIM-1, IL- 18, and L-FABP before and 2, 4, 8, 24, and 48 hours after cardiac catheterization, and observed a significant rise in L-FABP 24 and 48 hours after PCI in both groups without any significant changes 2-8 hours after the procedure (in diabetics: baseline $=6.39(0.96-7.21) \mathrm{pg} / \mathrm{ml}, 8 \mathrm{~h}$ value $=10.43$ $(2.31-51.33) \mathrm{pg} / \mathrm{ml}, 24 \mathrm{~h}$ value $=18.92(5.43-112.12)$ $\mathrm{pg} / \mathrm{ml}$; in non-diabetics: baseline $=5.32(0.64-5.43)$ $\mathrm{pg} / \mathrm{ml}, \quad 8 \mathrm{~h}$ value $=6.38(0.88-22.27) \mathrm{pg} / \mathrm{ml}, 24 \mathrm{~h}$ value $=16.01(4.17-98.45) \mathrm{pg} / \mathrm{ml})$; on the other hand, Serum cystatin $\mathrm{C}$ increased significantly after
8 hours, reaching its peak 24 hours after cardiac catheterization in both groups. In patients with CIN, Cystatin $\mathrm{C}$ was higher only 8 and 24 hours after cardiac catheterization, whereas L-FABP was significantly higher only 24 hours after the procedure.

Surprisingly, no additional diagnostic value of cystatin $\mathrm{C}$ over serum creatinine in the determination of CIN was observed when Ribichini et al., (2012) [33]; studied the diagnostic accuracy of serum creatinine and cystatin $\mathrm{C}$ as early predictors of CIN; they found that serum Cys concentrations did not reach statistically significant differences in the CIN+ vs CIN-groups, including at $48 \mathrm{~h}$, while Serum creatinine in $\mathrm{CIN}+$ patients was significantly higher than in the CIN- group only after $48 \mathrm{~h}$. Moreover, they found that absolute changes in serum creatinine proved more accurate than Cys for predicting CIN at an early stage (12 h after the renal insult). The $\Delta$ serum creatinine at 12 $\mathrm{h}$ from baseline was a strong predictor of CIN $(\mathrm{AUC}=0.80)$, while the $\Delta$ Cys at $12 \mathrm{~h}$ from baseline was not predictive of CIN (AUC $=0.49$ ).

Our study demonstrated statisitically sginificant correlations between $6 \mathrm{~h}$ urinary L-FABP (ng/dl) and each of the following: 6h plasma cystatin $\mathrm{C}$ (mg/l), eGFR ( $\mathrm{ml} / \mathrm{min})$ and amount of IV (highosmolar) contrast (ml) in AKI group. Statisitcally significant correlations were also present between $6 \mathrm{~h}$ plasma Cystatin $\mathrm{C}(\mathrm{mg} / \mathrm{l})$ and each of the following: 6h urinary L-FABP (ng/dl), eGFR ( $\mathrm{ml} / \mathrm{min}$ ), and amount of IV (high-osmolar) contrast (ml) in AKI group.

24h urinary L-FABP (ng/dl) was significantly correlated with each of the following: $24 \mathrm{~h}$ serum creatinine $(\mathrm{mg} / \mathrm{dl}), 24 \mathrm{~h}$ plasma cystatin C $(\mathrm{mg} / \mathrm{l})$, eGFR ( $\mathrm{ml} / \mathrm{min}$ ) and amount of IV (high-osmolar) contrast $(\mathrm{ml})$ in the AKI group. There were statistical significant correlations between $24 \mathrm{~h}$ plasma Cystatin C (mg/l) and each of the following: $24 \mathrm{~h}$ serum creatinine $(\mathrm{mg} / \mathrm{dl}), 24 \mathrm{~h}$ urinary L-FABP ( $\mathrm{ng} / \mathrm{dl})$, eGFR ( $\mathrm{ml} / \mathrm{min})$ and amount of IV (highosmolar) contrast ( $\mathrm{ml}$ ) in the AKI group.

In our study, it was found that basal values of both Cystatin C and L-FABP were equally sensitive as predictors of CI-AKI before contrast administration (sensitivity $=81.8 \%$ ), however, LFABP was more specific (specificity $=77.3 \%$ ) versus $59.1 \%$ for Cystatin $\mathrm{C}$ at cutoff values of $0.875 \mathrm{mg} / \mathrm{l}$ for Cystatin $\mathrm{C}$ and $10.5 \mathrm{ng} / \mathrm{ml}$ for $\mathrm{L}$ FABP; while combined Cystatin C and L-FABP had higher sensitivity and less specificity than either one of them (Sensitivity=90.9\%; Specificity $=45.5 \%$ ) as 
predictors of contrast nephropathy before contrast exposure.

Receiver operating characteristic (ROC) curve analysis showed that the area under curve (AUC) of basal urinary L-FABP $=0.837(95 \% \mathrm{CI} ; 0.673-$ $1.001)$, indicating good performance as a predictor for CIN before contrast exposure; basal plasma Cystatin $\mathrm{C}$ had a fair predictive ability with AUC of 0.742 (95\%CI; $0.600-0.925)$; while, basal serum creatinine was a poor predictor of CIN with an AUC $=0.636(95 \% \mathrm{CI} ; 0.470-0.856)$.

Contrast volume had an AUC of $0.812(95 \% \mathrm{CI}$; $0.653-0.971)$, indicating a good predictive ability for CIN.

In agreement with our finding, Nakamura et al., (2006) [25]; found that urinary L-FABP level was the best predictor of CIN among multiple predictive variables.

In their larger study, Manabe et al., (2012) [30]; found that for urinary L-FABP, The AUC was 0.70 before contrast administration. Through multivariate analysis, L-FABP level of $\geq 24.5 \mu \mathrm{g} / \mathrm{g}$ $\mathrm{Cr}$ was found to be an independent predictive biomarker of CI-AKI before contrast administration.

It worth noting that the aforementioned studies didn't include cystatin $\mathrm{c}$ as a biomarker for detection of CIN; and that conflicting result were obtained by Kato et al., (2008) [27]; who found that serum cystatin $\mathrm{C}$, at a cut-off level of $>1.2(\mathrm{~g} / \mathrm{l})$ exhibited 94.7\% (95\% CI: 0.851-1.015) sensitivity and $84.8 \%$ specificity for detecting CIN; serum cystatin C level was the only independent variable factor to detect CIN (cystatin $\mathrm{C}: \mathrm{p}=0.028$ ). This might be related to low patient number (33 patients) in our study compared to 87 patients in their study; all of them underwent coronary angiography.

The sensitivity and specificity of urinary LFABP at $6 \mathrm{~h}$ after adminstration of IV (highosmolar) contrast was $100 \%$ and $90.9 \%$ respectively at a cut-off value of $17.5 \mathrm{ng} / \mathrm{ml}$. Plasma CysC had similar sensitivity and more specificity $(100 \%$ and $95.5 \%$ respectively) at a cut-off value of 1.025 $\mathrm{mg} / \mathrm{l}$. Combined Cystatin C and L-FABP had $100 \%$ sensitivity but less specificity of $86.4 \%$.

When analysing ROC curve for biomarker values at 6 hours after contrast administration, there was an excellent performance of both urinary LFABP (ng/ml) and plasma cystatin C $(\mathrm{mg} / \mathrm{l})$ with an AUC for L-FABP $=1(95 \% \mathrm{CI}, 1-1)$ and that of cystatin $\mathrm{c}=1(95 \% \mathrm{CI}, 1-1)$, while the AUC of serum creatinine $(\mathrm{mg} / \mathrm{dl})$ was $0.683(95 \% \mathrm{CI} ; 0.443$ -0.830 ), indicating poor ability for detecting CIN at 6 hours after contrast administration.
Logistic regression analysis was done among variables predicting AKI before contrast exposure; urinary L-FABP at a cut-off value of $10.5 \mathrm{ng} / \mathrm{ml}$ was the best independent variable factor to predict CI-AKI (L-FABP: $p=0.008 ; 95 \%$ CI (1.998108.838)).

The limitation to our study is its relatively small sample size; thus, the predicted cutoffs for the studied biomarkers may be different from that obtained in other studies.

In conclusion, urinary L-FABP and plasma Cystatin $\mathrm{C}$ can considered as predictive biomarkers of AKI before contrast exposure and as early biomarkers of contast induced nephropathy 6 hours after contrast exposure instead of serum creatinine.

\section{REFERENCES}

1. Kidney Disease: Improving Global Outcomes (KDIGO) Acute Kidney Injury Work Group (2012). KDIGO Clinical Practice Guideline for Acute Kidney Injury. Kidney inter.; 2: 1-138.

2. Nash K, Hafeez A, Hou S. (2002): Hospital-acquired renal insufficiency. Am J Kidney Dis; 39: 930-936.

3. Ronco C, Stacul F, McCullough PA (2012): Subclinical acute kidney injury (AKI) due to iodinebased contrast media.. Eur Radiol.;23(2):319-23.

4. Rosner MH and Okusa MD.(2006): Acute kidney injury associated with cardiac surgery. Clin J Am Soc Neprol ; 1: 19-32.

5. Hawkins R (2011): New Biomarkers of Acute Kidney Injury and the Cardio-renal Syndrome. Korean $\mathrm{J} \mathrm{Lab}$ Med.; 31(2): 72-80.

6. de Geus H, Betjes M, and Bakker J (2012): Biomarkers for the prediction of acute kidney injury: a narrative review on current status and future challenges. Clin Kidney J.; 5: 102-108

7. Cho E, Yang H, Jo S, et al. (2013): The Role of Urinary Liver-Type Fatty Acid-Binding Protein in Critically Ill Patients J Korean Med Sci.; 28(1): 100105.

8. Moore E, Bellomo R, Nichol A. (2010): Biomarkers of acute kidney injury in anesthesia, intensive care and major surgery: from the bench to clinical research to clinical practice. Minerva Anestesiol.; 76(6):425-40.

9. Stevens LA, Coresh J, Schmid CH et al. (2008): Estimating GFR using serum cystatin $\mathrm{C}$ alone and in combination with serum creatinine: A pooled analysis of 3,418 individuals with CKD. Am J Kidney Dis 51: 395-406.

10. McIlroy DR, Wagener G, and Lee HT. (2010): Biomarkers of acute kidney injury: an evolving domain. Anesthesiology; 112: 998-1004.235

11. Khan E, Batuman V, and Lertora JJ (2010): Emergence of biomarkers in nephropharmacology. Biomark Med.;4(6):805-14

12. Herget-Rosenthal S, Marggraf G, Husing J, et al. (2004): Early detection of acute renal failure by serum cystatin C. Kidney Int $66: 1115-22$. 
13. Thomas L (1998): Alanine aminotransferase (ALT), Aspartate amino-transferase (AST). In: Clinical laboratory diagnostics. Thomas L (Ed.), TH-Books Verlagsgesell schaft, Frankfurt/Main,P. 55-65.

14. Henry RM (1974): Estimation of serum creatinine. Principal of clinical chemistry; 2: 525-37.

15. Fawcett JK and Scott JE (I960): A rapid and precise method for determination of urea. J. Clin. Path.; 13: 156-59.

16. Levey AS, Coresh J, Greene T, et al. (2006): Chronic Kidney Disease Epidemiology Collaboration Using standardized serum creatinine values in the modification of diet in renal disease study equation for estimating glomerular filtration rate..Ann Intern Med.15;145(4):247-54

17. Richmond W (1973): Quantitative-enzymatic determination of total cholesterol. Clin Chem.; 19: 1350-53.

18. Buccola G and David M(1973): Enzymatic determination of triglyceride. Clin. Chem.; 19: 47679.

19. Finley P (1973): For determination of high-density lipoprotein (HDL) cholesterol in serum. Clin. Chem.; 24: 231-37.

20. Kaplan A, Szabo L and Opheim KE (1988): Clinical chemistry interpretation and techniques. Harper's Biochemistry; 2: 119-23

21. Hossain M, Emara M, El moselhi. H, Shoker A (2009): Comparing measures of Cystatin $\mathrm{C}$ in human sera by three methods. Am J Nephrology 29(5): 381 391

22. Mehran R and Nikolsky E (2006): Contrast-induced nephropathy: Definition, epidemiology, and patients at risk. Kidney International 69, S11-S15.

23. Bellomo R, Kellum JA and Ronco C (2004): Defining acute renal failure: physiological principles. Intensive Care Med. 30:33-37.

24. Herget-Rosenthal S, Marggraf G, Husing J et al. (2004): Early detection of acute renal failure by serum cystatin C. Kidney Int, 66 :1115-22.
25. Nakamura T, Sugaya T, Node K, et al. (2006): Urinary excretion of liver-type fatty acid-binding protein in contrast medium-induced nephropathy. Am J Kidney Dis; 47:439-444.

26. Kamijo-Ikemori A, Sugaya T, and Kimura K (2006): Urinary fatty acid binding protein in renal disease. Clin Chim Acta 2006; 374: 1-7.

27. Kato K, Sato N, Yamamoto T, et al. (2008): Valuable Markers for Contrast-Induced Nephropathy in Patients Undergoing Cardiac Catheterization. Circ J; 72: 1499-1505

28. Bachorzewska-Gajewska H, Poniatowski B and Dobrzycki S (2009): NGAL (neutrophil gelatinaseassociated lipocalin) and L-FABP after percutaneous coronary interventions due to unstable angina in patients with normal serum creatinine Adv Med Sci.;54(2):221-4.

29. Ohta S, Ishimitsu T, Minami J, et al. (2005): [Effects of intravascular contrast media on urinary excretion of liver fatty acid-binding protein]. [Article in Japanese] (Abstract). Nihon Jinzo Gakkai Shi.; 47(4):437-44.

30. Manabe K, Kamihata H, Motohiro M, et al. (2012): Urinary liver-type fatty acid-binding protein level as a predictive biomarker of contrast-induced acute kidney injury. Eur J Clin Invest. May;42(5):557-63.

31. Shaker OG, El-Shehaby A, and El-Khatib M (2010): Early diagnostic markers for contrast nephropathy in patients undergoing coronary angiography. Angiology.;61(8):731-6.

32. Malyszko J, Bachorzenwska-Gajewska $\mathrm{H}$, Poniatowski B, et al. (2009): Urinary and serum biomarkers after cardiac catheterization in diabetic patients with stable angina and without severe chronic kidney disease. Ren Fail.; 31(10):910-9.

33. Ribichini F, Gambaro G, Graziani MS, et al. (2012): Comparison of serum creatinine and cystatin $\mathrm{C}$ for early diagnosis of contrast-induced nephropathy after coronary angiography and interventions. Clin Chem.;58(2):458-64. 


\section{دراسة بروتين الاتحاد بالحمض الدهني من النمط الكبدي بالبول

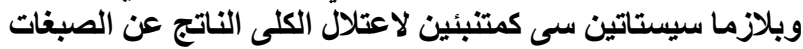

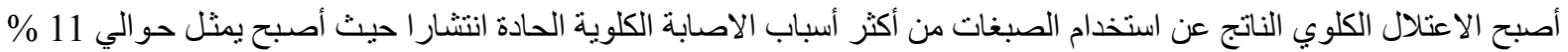

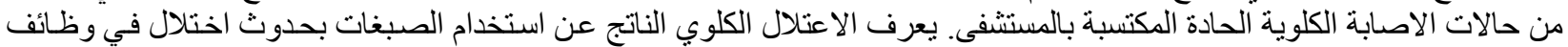

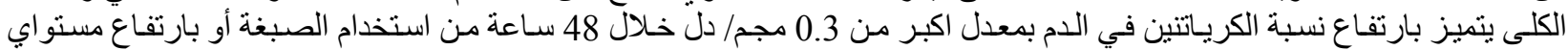

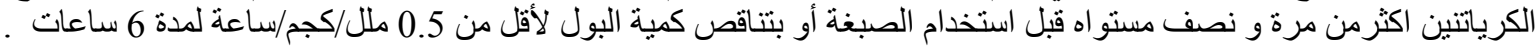

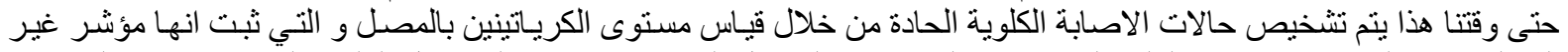

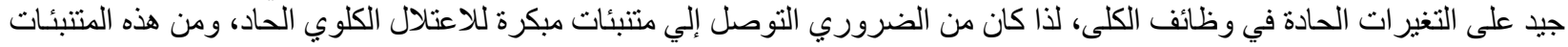

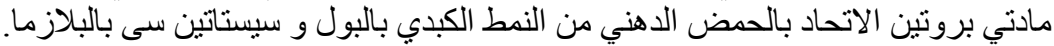

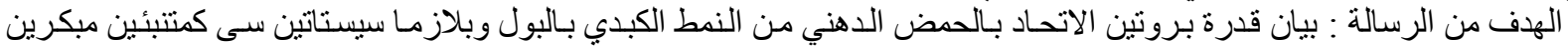

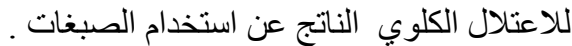

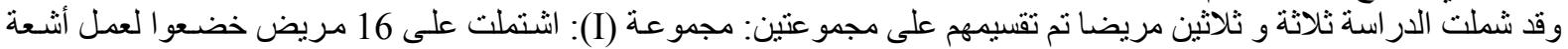

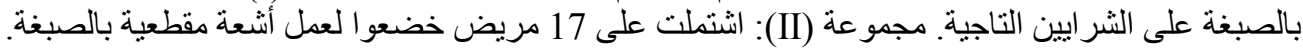

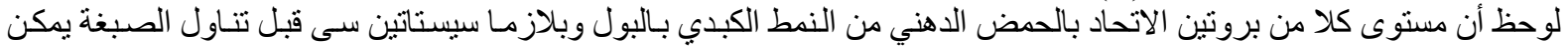

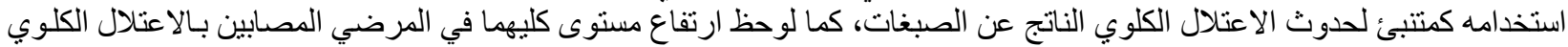

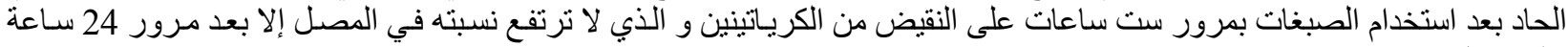
على الاقل. وبالتالي فقد خلصت الدراسة الي انه يمكن اعتبار كلا من بروتين الاتحاد بالحمض الدهني من النمط الكبدي بـالبول وبلازما سيستاتين

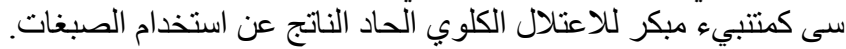

